\title{
Professional engagement in child protection: promoting reflective practice and deeper connection with the lived reality for children
}

DOI 10.1515/ijtr-2015-0010

received September 2015; accepted November 2015

\begin{abstract}
This paper uses first person inquiry and presentational form to argue the case for a sensory approach to understanding professional connection and disconnection with children who may be being abused. The approach is underpinned by an epistemology or theory of knowledge which stems from a participatory world-view where appearances are not permanent or separate from us: the act of perception takes place between the active sensible world and our own bodies, where 'otherness' expresses itself directly to our senses. Thus perception, conceived in this way, can lead to right action in the moment; or discounting what is actually being said by a child and disconnection. Buber's notion of the 'I-You' is used to explore feelings and the movement to relation when professionals witness children's 'stories of suffering' (Buber, 1965; Laub, 1992; Jones, 2008). The paper concludes by arguing the case for practitioners to become researchers of their own practice in rigorously facilitated inquiry groups. It is argued that this form of practitioner-research serves to quality assure frontline practice, and create new knowledge (or practice wisdom) such that feelings can be constructively worked with to improve connection with the lived reality for children.
\end{abstract}

Keywords: Child protection, supervision, reflective practice, work discussion, action research, ethnography.

\footnotetext{
*Corresponding author: Jocelyn Jones, Director, Mindful Practice Ltd, Honorary Research Fellow, Royal Holloway, University of London, and Visiting Fellow, Bournemouth University, UK, E-mail: jocelyn.jones@mindfulpractice.co.uk
}

\section{Introduction}

Over the past few years in England, public interest and outrage have been fuelled by media coverage of a number of high profile child abuse cases. Several have involved child sexual exploitation on an unprecedented scale, along with police investigations into historical abuse involving former media 'celebrities' and institutions. Following on from the well-documented 'Baby P' case, the deaths of three other young children, also reported in Serious Case Reviews - Daniel Pelka, Keanu Williams and Hamzah Khan - also come immediately to mind. Against the 'high stakes' backdrop of 24 hour new coverage and discussion on social media, professional practice is under scrutiny, and reputations on the line like never before. It is therefore easy to see why the day to day business of safeguarding children and young people can become characterised by anxiety, uncertainty, inaction, and blame, which reverberate around the system designed to protect them (Munro, 2011 \& 2012).

At the same time, central and local government politicians and the general public expect the professionals, who they charge with caring for the most vulnerable members of our society, to manage responses to child abuse allegations with a degree of timely certainty; and then act swiftly and decisively in the child's best interests. However getting it right first time, especially in complex cases, such as child sexual exploitation, is extremely demanding: professionals may not realise a case is complex or may need a different approach, unless they start connecting with the child's or children's stories and share that information appropriately across agencies, and regional and national boundaries, as required. With this degree of potential complexity, there is a growing argument for practitioners and managers to be able to access safe yet challenging spaces for reflective case discussion to process their anxiety, thoughts and feelings and formulate different hypotheses about what might be happening in a case using intellect \& emotion, and analytic \& intuitive reasoning processes (Jones, 2008; Jones, 2011; Jones, 
2014; Munro, 2008). It is the well-supervised, highly motivated, emotionally attuned, curious and compassionate professional who makes the difference in a child's life; the one who notices subtle signs - when a child is 'on edge' or more withdrawn or when s/he speaks in coded language and acts in the child's interest.

And yet, this same professional is also a human being with all her/his strengths and vulnerabilities which intermingle and sometimes compete in the decision making and ultimate response to a child's circumstances. It is in this complexity that the values and ethics of a person can either 'shine' or be compromised. Child protection is the domain of the unpredictable; using Donald Schön's terminology, it is a 'swampy lowland', where the 'indeterminate zones' of everyday practice are preoccupied with 'the problems of greatest human concern' (Schön, 1987, pp. 3-6); it can also be life threatening for all those involved (Stanley and Goddard, 2002).

From cases I've been involved with over the years, I know that feelings, emanating from a child-centred value base and leading to appropriate action, can fundamentally alter a child's life for the better. When such values are not evident, equally strong but different feelings, such as the flight response or the need to be liked, may flood a professional and lead to a child being in effect abandoned or collusive practice with her/his carers. I am going to use the story of a child, who had a profound influence on my understanding of practice, to illustrate how much feelings influence connection or disconnection with the lived reality for children and young people who may be being abused.

\section{Graham}

Graham was a severely neglected and abused child, who was allowed to slip through the net designed specifically for children like him. This extract from my report, written at the time as Graham's Guardian ad Litem, gives an idea of the kind of child he was when I first met him, aged eight:

Graham was always enthusiastic whether it was a trip to "McDonalds", the play people, opening my car doors with the keys, carrying the toys, reading books, drawing, playing with puppets or doing jigsaws. He demonstrated a concern about my needs e.g. passing me my seat belt after I had secured him in his, offering me "fries", or asking me if I wanted to eat when he was having his tea.

To me he was a child in desperate need of relationship. There is something very sad about the loss of his potential as a human being: as a baby and toddler, he was denied a home life which met a developing child's needs for relationship and love (Gerhardt, 2003). How does a healthy baby whose condition was excellent at birth, with normal development noted up to twelve months only possess a mere handful of words, like Woof and $\mathrm{F}^{\star \star} \mathrm{k}$, at two years of age? How and why did he completely fail his two and three year developmental screening? At this stage we - you, the reader and I - could easily jump into blame of the professionals involved in his early life, but let's experience the circumstances of Graham's life in a different way. I invite you on my first visit to the estate where he lived. ${ }^{1}$

\section{Entering the Child's World}

So now it's time to join me in my boring little car on a depressingly grey and wet autumn afternoon, where we really don't quite know what or who we will encounter:

It was damp, dull October afternoon with a veil of fine rain. As I turned off the main road onto the housing estate, I entered a labyrinth of ever smaller and rougher roads which led to deep 'pockets of deprivation', discreetly hidden from the smart cars that sped up and down the highway.

I was getting closer to the address, and as I turned the corner, my heartbeat quickened: I saw the block of flats that had '225245 ' above the front door. There were three windows on the ground floor to the right of the entrance that caught my eye: one was boarded up and two had rags for curtains, which looked like they had been carefully coated in dirty chip fat. I prayed it would not be that flat.

My mouth seemed strangely dry. I needed somewhere to park. The car in front was a burnt out wreck and the one behind was abandoned. What would happen to my car, carefully chosen to be boring for this very reason? Would it still be here when I came out? I carefully parked it between the two and hoped that somehow it would dissolve into the misty greyness of the afternoon.

... A quick glance at my watch told me I had a minute or two to go until the appointed time: it was essential not to be late. Lateness can put you on 'the back foot' as you start by apologising to the carer(s); it also signifies a lack of respect. Deep breath out. A further glance at the watch and it's time to go. Another deep breath out.

A brisk walk down the concrete path with worn patches of grass on either side, dotted with discarded cigarette ends; I enter the

1 Graham is a pseudonym and factual details relating to people and place in the story have been changed to protect his identity. The learning from the home visit is unchanged. 
hall of the flats. In that moment I catch the number of the flat on the battered door. It is that flat...

The battered door has what looks like dog shit smeared over it; and I have to knock on it. A feeling of revulsion and dread wells up in the pit of my stomach.

My lips and mouth are now completely dry and taste like cardboard. I brace myself. Somewhat gingerly, I knock the door going for the cracked dirty cream paintwork between the brown crescent-shaped smears. The lesser of two evils, perhaps?

Darkness as the light in the stairwell goes out. Silence from the flat inside.

A sigh of relief, albeit temporary; my shoulders drop slightly. A temporary thought flashes across my brain: "Thank goodness there's nobody in; I could leave right now and wouldn't have to do the visit." It's tempting but I've been here before: “Jocelyn, you need to stick it out."

So there is no easy escape into the relative safety of my boring little car.

I press the switch in the hall again. The light comes on. I sense that there is somebody in. Are they pretending to be out?

I knock louder. A shuffling sound from inside. Some muffled voices. The door opens slowly an inch or two and I introduce myself. Identification is demanded of me. Strange? This is the first time I've ever been asked for ID and I had sent a letter on headed stationery in advance and I'm exactly on time...

There is no light bulb in the corridor and a thick, yellow smoky haze is all that can be seen at the end. I panic. As an asthma sufferer, the thought of sitting in a smoke-filled room with those strangers brings still more dread. Will I be able to breathe? Why are they there?

The short walk down the dark corridor feels like a descent into another, as yet unknown world. All my natural instincts are telling me to get the hell out of here. And yet I have to fight them every inch of the way, whilst not directly exposing myself to overt danger. I ask Harold to lead the way so that my exit is clear.

The sitting room, if that's what you would call it, is overwhelmingly a dirty yellow brown and smoke-filled. The wallpaper is torn and there are brown smears which look like shit all over it at a child's height. The once beige synthetic carpet is matted together into a dirty blackness: years of ingrained filth have found their niche and give a sticky matt black charcoal finish in the most worn areas. Between Harold's armchair and the fire and in the fire there is a light dusting of cigarette ash. Hasn't anybody pointed out that the fire is electric coal effect, not the real thing?

So I am directed to the brown plastic sofa next to a woman with false teeth and shrunken gums, probably in her late thirties. The sofa plastic has been shredded and sticks into the back of my thighs. I am beginning to feel sore after only a few minutes. How long can I endure this? I want to leave, but I cannot and will not: I have a job to do.

And so the verbal assault on me starts, perhaps even intimidation. A concerted effort from the pair of them to get me to back off and to force my gaze towards the adult agenda: "How dreadful of them police and social services to take my Graham away to that children's home."

Well, I think to myself, he is only eight, has learning difficulties and a history of neglect and was found at the home of a convicted paedophile, a near neighbour.

Eventually, the woman gets bored and leaves after saying her piece. She lives just down the road with another convicted sex offender.

Now it's just the two of us.

I notice the way Harold wheezes and hobbles every time I move to the child's agenda. He's in his sixties and makes sure I am fully aware of his seemingly endless list of health problems. When I start focusing on him and his problems, the wheezing, spluttering and staggering miraculously stop. Interesting. There is some stage-managing going on here.

Yes, Graham did smear on the walls, but predictably it's all the child's fault: "He’s a b ${ }^{\star \star \star \star}$, you know."

I force myself to look around the rest of the flat. The kitchen has plates piled up to shoulder height in the sink. Scraps of mouldy food wedded to white plastic. A frying pan with a cooked egg immortalised in a solid white fat speckled with black flecks of burnt food from a prior age.

The bath is filled with soiled clothes. The white of pyjama stripes barely discernible in a brown putrid soup. The edge of the toilet is cracked. I dare not even look.

The beds have no sheets or pillows on them, just dirty eiderdowns.

The first visit almost done. I linger a moment longer. I feel dreadful.

If I feel like this, what do I think it was like for Graham living here for eight years of his life? Graham, whose mother died of pneumonia on that very bed when he was just five.

Remember this.

As I leave, my mind is full. Of intimidation, of manipulation, of poverty and deprivation, of child neglect, of possible child sexual abuse and just who is this man who says he's Graham's father?

There is darkness outside now, but I can breathe again. The cool of the rain and the freshness of the damp air hit my face. My exit is clear: nobody seems to have tampered with my boring little car. 
The backs of my sore thighs sink with relief into the synthetic smoothness of the driver's seat. The engine starts and I speed away onto the main road. So for a few days, I leave behind what was Graham's home for a world that is more familiar. I return to the giggles and capers of my two daughters in their nightclothes, fresh from their bath. An early evening disco in front of the open fire in a 'normal' front room, soft shadows dancing on the walls in the warm glow of the flickering heat.

After story and bedtime, I record more details of the visit. The question uppermost in my mind, the question I need to answer is: What was it like for Graham to live in that flat in that neigh bourhood with sex offenders as his near neighbours? Other questions surface and buzz around my brain: Why was this child not removed earlier? What did the various professionals involved think they were doing? What does Graham understand about his mother and her death . . . at home? Why didn't his alleged father seek medical help for his mother when she was seriously ill? Is this man really his father or did he seek to exploit the vulnerability of Graham's mother, a woman with learning difficulties who had already lost her twin daughters to social services because the children's father was a 'risk to children'? ${ }^{2}$

(C) 2008 Jocelyn Jones. All rights reserved.

\section{Reflection: a participatory worldview}

How do you feel? Did you share a sense of contamination from entering Graham's world? Might you want to wash your hands, or even have a bath and change your clothes after the visit? Whenever I tell this story to a professional audience, there is always a nervous giggle early on which goes right round the room. This is at the point when I describe my internal dialogue around the first knock on the door, and the temptation to disappear as fast as I could 'into the safety of my boring little car'. Virtually all practitioners have been there, perhaps slightly 'off-colour' that day or pressed for time or just plain scared. And yet, it is very difficult to reveal vulnerability, the effects of stress, or straightforward revulsion about a family home within a 'caring' profession such as social work.

My heightened level of consciousness, fuelled by what I had seen, smelt, tasted, heard and felt, propelled me into a deep concern for Graham, a vulnerable and neglected child, whose needs had been largely invisible to previous professionals. At the end of the visit I came away with a determination to 'get to the bottom' of his circumstances and also to understand why none of the professionals had intervened earlier. Towards the end of my assessment I

2 Home Office Circular 16 / 2005 asked the two main practitioners, who had both worked for several years with the family, how s/he had each felt about visiting Graham's home. They were both extremely frank; and replied, independently of each other, that they hated going there - more so than any other house.

What helps us respond to feelings like dread and repulsion, and then transcend them to connect with the lived reality for Graham and children like him? My epistemology or theory of knowledge for effective child protection practice stems from a participatory world-view where the natural world is a dynamic presence which draws us into relation, thus influencing what can be known (Dewey, 1981; Abram, 1996; Reason, 1994; Reason and Bradbury, 2001; Thayer-Bacon, 2003). This underpinned the 'Entering the child's world' story where I used presentational form (Heron and Reason, 1997 \& 2001) to draw out the experiential knowledge of the circumstances in which Graham lived, gleaned through my senses: we live in a unified, connected world that is alive, dynamic and constantly changing where appearances are not permanent or separate from us. Abram (1996) warns of the objectifying consequences of cutting ourselves off from our sensing bodies:

Our most immediate experience of things, according to Merleau-Ponty, is necessarily an experience of reciprocal encounter - of tension, communication, and commingling. From within the depths of this encounter, we know the thing or phenomenon only as our interlocutor - as a dynamic presence that confronts us and draws us into relation. We conceptually immobilize or objectify the phenomenon only by mentally absenting from this relation, by forgetting or repressing our sensuous involvement. To define another being as an inert or passive object is to deny its ability to actively engage us and to provoke our senses, we thus block our perceptual reciprocity with that being. By linguistically defining the surrounding world as a determinate set of objects, we cut our conscious, speaking selves off from the spontaneous life of our sensing bodies. (Abram, 1996, p.56)

There is a strong imperative - not least from an evidential and legal perspective - for practice to appear clinical. However when visiting children and families, body and mind are working together, and the senses play a key role: the act of perception is like a dance between the active sensible world and our bodies, where 'otherness' expresses itself directly to our senses.

Using the philosophy of Merleau-Ponty, Abram (1996, p. 68) goes on to discuss the participatory nature of touch:

[Merleau-Ponty] calls attention to the obvious but easily overlooked fact that my hand is able to touch things only because my hand is a touchable thing, and thus is entirely part of the tactile world that it explores. Similarly, the eyes, with which I 
see things are themselves visible ... We can experience things - can touch, hear and taste things - only because, as bodies, we are ourselves included in the sensible field, and have our own textures, sounds, and tastes. We can perceive things at all because we are only part of the sensible world that we perceive.

Thus our perception of the sensible field can lead to right action in the moment; or discounting what is actually being said by a child, perhaps when the timing is inconvenient, as I will discuss later in relation to my own practice. It may also lead to professional flight, for example when flooded by feelings of anxiety or fear. This may be because of intimidation, the threat of or actual violence, and/or earlier traumatic experiences as a child being triggered as an adult. It is therefore vital that the possibility of professional minimisation and inaction are on the supervision agenda. This becomes even more important when considered alongside psychological research which shows that people like to hold onto their beliefs despite fresh evidence that challenges their opinions (Bacon, 1960 [1620]; Janis and Mann, 1977; Nisbett and Ross, 1980; Munro, 2008); moreover, the longer an incorrect hypothesis is stuck to the more difficult it may become for professionals to change their minds. This can be equally harmful whether the degree of risk to the child is being under- or over-estimated (Munro, 2008). It is therefore crucial for children in need and child protection professionals to play their own 'Devil's Advocate' from time to time in the form of first person inquiry practices (Marshall, 2001); and to adopt second person inquiring and challenge roles with and for colleagues in a safe reflective space (Heron and Reason, 2001; Reason and Torbert, 2001). In such a practice forum, which is essentially a form of quality assurance, the reasoning processes behind decision making and connection with the lived reality for a child can be explored in more depth (also see Ofsted, 2012).

\section{Coming into relation: an exploration of connection and disconnection}

During the time I worked with Graham, he started to use red play people and the colour red to reveal through play some of the traumatic experiences he had witnessed. The colour blue signified the world in which he and I worked together in real-time. I now see our relationship as based on Martin Buber's notion of the 'I-You', which represents a twofold attitude to being (Buber, 1965).
In the I-You mode of existence the interpersonal is permeated: 'This constitutes a movement to relation and establishes in the interpersonal space a quality Buber refers to as "the between". "The between" then, belongs to the I-You relation' (Avnon, 1993, p.57). An attitude to relation that derives from a fragmented sense of self Buber calls I-It. This is where a person, for whatever reasons, distances her/himself from the other. The interpersonal is characterised by a stress on difference.

People move between states of being, between fragmentation and inner unity: the I-You attitude to relation cannot be kept up indefinitely. Buber draws a distinction between two different attitudes to being: the "ego oriented I" and the "person oriented I":

For an ego oriented I, self-knowledge is knowledge of a limited, partial aspect of one's existence yet considering it the whole; for the person-oriented I, self-knowledge is knowledge of self as being. The person-oriented I is one who can shift from an erroneous perception of him- or herself as the center of being, to a recognition of relation as the center of being. (Avnon, 1993, p.58)

I am now going to illustrate how, on one very important occasion, I distanced myself from Graham: becoming an "ego-oriented I" and thus moving out of the I-You mode of being. During this session, which happened to be on my birthday, Graham started to describe a violent scene that he had witnessed. As he talked and drew vigorously using mainly a thick red pen, I was aware of the energy between us and in the room as he shared what had happened. After what seemed a long time to me, although perhaps not longer than an hour or so, I noticed I was disengaging; my hope was that he would become tired thus bringing the session to a natural close. I had reached saturation point: it was my birthday and I wanted to go home to the waiting celebration.

I motioned to Graham that perhaps it was time to start putting things away, but he said "You're not going. Want you to play." ${ }^{3}$ I realised that birthday or no birthday I had to stay to help ease him out of the traumatic experience he had described. I also regretted holding the session in his bedroom at the children's home, because he had to sleep in that space after I left him, alone with the memories of what he had told me. This was perhaps the first time that I really appreciated the importance of the right physical space to promote relation and yet provide safe boundaries for me and the other person. It was also the last interview I ever did of that nature on my birthday or when I had a similar important engagement.

3 Quote taken from my contemporaneous notes of the interview. 
When encountering another's narrative early on, we have little preliminary knowledge of the emotional terrain we are about to traverse. For example, when I arranged this session with Graham, I had no idea he had witnessed the violent scene he described to me. All I knew then was that he had been neglected and that he might have been sexually abused. My initial response - to leave as soon as I reasonably could for my waiting birthday party - was quite rational at an ego-oriented, self-interested level; almost the same as the relief of returning to the safety of my boring little car when there was no response to the first knock on the faeces-smeared front door. However, this denied my professional responsibility as a witness to his trauma. Laub (1992) powerfully reminds us what might be at issue here:

Bearing witness to a trauma is, in fact, a process that includes the listener. For the testimonial process to take place, there needs to be a bonding, the intimate and total presence of an other - in the position of the one who hears. Testimonies are not monologues; they cannot take place in solitude. The witnesses are talking to somebody: to somebody they have been waiting for for a long time. (Laub, 1992, pp.70-71)

Referring to narratives of extreme human pain, Laub reminds us of the importance of bearing witness, of listening to and hearing the Other for healing to begin. This, Laub argues, involves transferring a story to a person outside of oneself, and then taking it back inside again. This dyadic relation is the recognition that even though our bodies might be physically separate, 'this other has to do with me as I with it '(emphasis added by Frank, 1995, p.35; Buber, 1958).

The person who constructs her/his narrative is telling her/himself to the person who bears witness; and in so doing is constructing and reconstructing experiences for another: 'it is this bearing witness to the other, spoken or not, that gives birth to the $I$ (Oliver, 2001, p.207). The inner witness can come forth because there is an outer witness who responds (Laub, 1992). This is why face-to-face contact is so important when bearing witness to stories of suffering, but actions which promote trust and self-esteem either side of the actual encounter(s) are of equal importance. Children (and adults) who have been neglected invariably have low self-esteem, and often blame themselves for what has happened in their families. It is the task of professionals to use every opportunity possible to re-build a more positive sense of self with and for children so that they eventually develop sufficient courage to tell their story and have it witnessed by a responsive professional. For the final part of this paper I outline a few ways this might be done, and make some recommendations for the learning and development needs of frontline staff working in child protection.

\section{Conclusion: responsiveness and space to promote connection}

Protecting children is one of the most worthwhile yet challenging roles that a professional can be required to perform. Much of the focus tends to be on the interview process itself. However connection with the lived reality for a child is an incremental process, one in which practical, trust-building, and participant-affirming responses become part of daily practice. This accountable, responsive approach, such as turning up on time, giving the child your full attention and doing what you say you'll do within agreed timeframes, builds the relational foundation for higher order, emotional connection with a child's circumstances. In this context we need to remind ourselves that some children may have been poised for some time to tell their story of suffering; and they will only share this story with someone who has demonstrated respect, attention and care in their daily actions. For example, my concern to ensure Graham's safety in my car and letting him exercise choice, however small, or remembering to bring something I had promised, helped build trust between us incrementally. This opened up the possibility for Graham to describe the violent scene he had witnessed. The values and ethics of a practitioner within a sensory, three dimensional dynamic understanding of the practice milieu, such as a child's home and family relationships, are fundamental to child-centred practice in this field.

Personal and professional body-mind, self-care practices, which promote a sense of wellbeing and a state of alertness and curiosity, enable the practitioner to connect emotionally with the child's circumstances; and then disconnect appropriately afterwards as they return home. Consciously moving between these two states protects practitioners from being flooded by the trauma of a child's narrative as they go about their daily lives. Although it is not appropriate to be overly prescriptive, the adoption of self-care practices for front-line staff needs to be encouraged for the child's story to be witnessed (Jones, 2008). This may include a blend of mindful practice meditation techniques, simple postures, breathing exercises and relaxations derived from yoga and Buddhist traditions (Schiffmann, 1996; Bentz and Shapiro, 1998; Agombar 1999 \& 2006; Beeken, 2000; De Rahm and Gill, 2001; Nelson, 2006; Jones, 2008). 
However as argued elsewhere, the intensity of the engagement process and responding well to the unexpected should not be under-estimated. It is therefore imperative that practitioners and managers be offered safe spaces to reflect on, challenge and ultimately improve practice. These spaces need to address 'real-world' human feelings and responses such as anger, frustration, collusion or flight from a child's circumstances; teach and rehearse tools and techniques for professional self-care and connection; and explore the practitioner's reasoning processes.

The preferred milieu and ground rules for reflective practice need to be developed collaboratively with practitioners and managers to ensure relevance, and promote ownership and participation. Work or case discussions should be supported by a culture which promotes learning from 'mis-takes' as well as good practice and 'success' stories. This may include, for example, concerns about being 'stuck' with a child or his/her family or worries about risk. At least one person, accorded the role of 'Devil's Advocate' on a rotating basis, needs to challenge the assessment by actively seeking out and working with preconceptions. In this way practitioners become researchers of their own practice through rigorous reflection-on-action in the form second person inquiry, which influences the quality of first person inquiry and the practitioner's real time reflection-in-action (Heron \& Reason, 2001; Reason \& Torbert, 2001; Marshall, 2001; Schön, 1983). Uncomfortable feelings, such as anxiety or revulsion, become data to be worked with alongside chronologies, conversations with family members, observations of children within different environments, and their relationships with family and friends. This form of practitioner-research facilitates the creation of new knowledge or practice wisdom such that feelings can be recognised, expressed and rigorously explored.

Finally and not least, careful consideration needs to be given to the physical space in which these practitioner-researcher forums take place i.e. away from the demands of the workplace in a quiet, comfortable room. The current 'austerity agenda' in the UK public sector has significantly eroded training and development budgets such that external venues are used far less often. Nevertheless, the concentration necessary for critical reflection on practice is compromised by busy office environments where bodies and minds can all too easily become distracted by sensory information impacting from several sources; and connection with the lived reality for a child therefore interrupted. Where group reflection on practice has been prioritised at strategic level within an agency, modest reflective spaces can be created from available internal accommodation and reserved. Informed by appropriate research evidence and competently facilitated either internally or externally, these practitioner-researcher forums have the potential to offer rigorous internal quality assurance for frontline practice, owned and managed by the practitioners and managers themselves.

Making sense of the lived reality for children and young people involves self-understanding as we seek to comprehend the frames that guide our interpretations of the circumstances of their lives. This requires each and every one of us, as individuals and in groups, to be able to learn from the prejudicial, shadow side of ourselves, for example, where we have perhaps acted out of self-interest rather than the child's best interests or experienced other incongruous aspects of ourselves in action - when we are in danger of becoming or have become a 'living contradiction' (Whitehead, 2000).

Profound learning emanates from circumstances when we have to respond to what is unfamiliar, what irritates, what disturbs (Biesta, 2006). In this unsettling context learning can become a creation, bringing forth one's own unique response; and with others, the possibility to create new narratives of professional honesty, co-operation and partnership. It also has the potential to offer fresh insights into the lives of children and young people, previously unseen and implicitly or explicitly written off as beyond help; where a child's story of suffering can be witnessed and transcended as the kernel of a new healing narrative begins to form.

Acknowledgements: I would like to express gratitude to my three PhD supervisors - Dr Steve Taylor, Dr Donna Ladkin and Prof. Jack Whitehead (2002-2008) for their distinctive and different contributions to the development of the ideas contained in this paper. I would also like to thank Dr Joan Walton for her encouragement and feedback on earlier drafts. 


\section{References}

[1] Abram, D. (1996). The Spell of the Sensuous. Perception and language in a more-than-human-world. New York, USA: Pantheon Books.

[2] Agombar, F. (1999). Beat Fatigue with Yoga. A Step-by-Step Guide. Shaftesbury: Element Books.

[3] Agombar, F. (2006). Beat Fatique with Yoga. The Simple Step-By-Step Way to Restore Energy. London: Cherry Red Books.

[4] Avnon, D. (1993). The "Living Centre" of Martin Buber's Political Theory. Political Theory, 21 (1), 55-77.

[5] Bacon, F. 1960 [1620]. Novum Organum. New York, USA: Liberal Arts Press.

[6] Beeken, J. (2000). Yoga of the Heart. Liss: White Eagle Publishing Trust.

[7] Bentz, V. M. \& Shapiro, J. J. (1998). Mindful Inquiry in Social Research. London \& Thousand Oaks, CA: Sage Publications.

[8] Biesta, G. J. J. (2006). Beyond Learning. Democratic Education for a Human Future. Boulder \& London, UK: Paradigm Publishers.

[9] Buber, M. (1958). I and thou. 2nd edition. New York, USA: Charles Scribner.

[10] Buber, M. (1965). The Knowledge of Man. London, UK: Allen \& Unwin.

[11] De Rham, C., Gill, M. (2001). The Spirit of Yoga. London: Thorsons.

[12] Dewey, J. (1981). The later works, 1925-1953: Vol. 10. Art as experience (J A Boyston, Ed.). Carbondale, USA: Southern Illinois University Press.

[13] Frank, A. W. (1995). The Wounded Storyteller. Body, Illness and Ethics. Chicago, USA \& London, UK: The University of Chicago Press.

[14] Gadamer, H-G. (1977). Theory, technology, practice: The task of the science of man. Trans. H. Broth. Social Research, 44(3), 529-561

[15] Gerhardt, S. (2003). Why love matters: how affection shapes a baby's brain. London, UK: Taylor \& Francis Ltd.

[16] Gibson, J. J. (1966). The Senses Considered as Perceptual Systems. Boston, USA: Houghton Mifflin.

[17] Heron, J. (1996). Co-operative Inquiry: Research into the Human Condition. London, UK: Sage Publications.

[18] Heron, J. \& Reason, P. (1997). A participatory inquiry paradigm. Qualitative Inquiry. 3(3), 274-294

[19] Heron, J. \& Reason, P. (2001). The Practice of Co-operative Inquiry: research 'with' rather than 'on' People. In P. Reason \& H. Bradbury (Eds.) Handbook of Action Research: Participative Inquiry and Practice. London, UK: Sage.

[20] Janis, I \& Mann, L. (1977). Decision Making: A Psychological Analysis of Conflict, Choice and Commitment. New York, USA: Free Press.

[21] Jones, J. (2008). Thinking with stories of suffering: towards a living theory of response-ability. (PhD thesis, University of Bath, UK). http://opus.bath.ac.uk/13444/ (accessed 20th October 2015)

[22] Jones, J. (2011). Promoting and Improving High Quality Assessment, Planning, Intervention and Review (APIR) Practice. Report of an Action Learning Project for South West Improvement and Efficiency Partnership. South West Councils
\& Mindful Practice Ltd. http://www.online-procedures.co.uk/ wp-content/uploads/2012/02/SWRIEP-APIR-Report-FINALAug-2011-2.pdf (accessed 20th October 2015)

[23] Jones, J. (2014). A Report from the Centre for Social Work Practice on Reflective Practice Group Models in Social Work. London: Centre for Social Work Practice. http://cfswp.org/ perch/resources/papers/reflective-practice-report-11.05.15.pdf (accessed 20th October 2015)

[24] Laub, D. (1992). Bearing Witness or the Vicissitudes of Listening. In S.Felman \& D.Laub Testimony Crises of Witnessing in Literature, Psychoanalysis and History. New York, USA: Routledge.

[25] Marshall J. (2001). 'Self-reflective Inquiry Practices'. In P. Reason and H. Bradbury (Eds.) Handbook of Action Research: Participative Inquiry and Practice. London, UK: Sage.

[26] Munro, E. (2008). Effective child protection. 2nd edition. London, UK: Sage Publications.

[27] Munro, E. (2011). The Munro Review of Child Protection: Final Report. Towards a child-centred system. Norwich \& London, UK: The Stationery Office. http://www.official-documents.gov. uk/document/cm80/8062/8062.pdf (accessed 20th October 2015)

[28] Munro, E. (2012). The Munro Review of Child Protection. Progress Report: Moving towards a child centred system. London, UK: Department for Education. https://www.gov.uk/ government/uploads/system/uploads/attachment_data/ file/198224/DFE-00063-2012.pdf (accessed 20th October 2015).

[29] Nelson, J. (2006). Empathy Overload? Yoga Journal. May: 41-43.

[30] Nisbett, R. \& Ross, L. (1980). Human Interference: Strategies and Shortcomings of Human Judgement. Englewood Cliffs, NJ, USA: Prentice Hall.

[31] Office for Standards in Education, Children's Services and Skills [Ofsted]. (2012). High expectations, high support and high challenge. Protecting children more effectively through better support for front-line social work practice. Manchester, UK: Ofsted. http://www.ofsted.gov.uk/resources/ high-expectations-high-support-and-high-challenge (accessed 20th October 2015).

[32] Oliver, K. (2001). Witnessing. Beyond Recognition. Minneapolis, USA: University of Minnesota Press.

[33] Reason, P. (Ed.) (1994). Participation in Human Inquiry. London, UK: Sage Publications.

[34] Reason, P. \& Bradbury, H. (Eds.) (2001). Handbook of Action Research: Participative Inquiry and Practice. London, UK: Sage.

[35] Reason, P. \& Torbert, W. (2001). The action turn: Toward a transformational social science. Concepts and Transformation, 6 (1), 1-37.

[36] Thayer-Bacon, B. (2003). Relational (e)pistemologies. Oxford, UK: Peter Lang.

[37] Schiffmann, E. (1996). Yoga. The Spirit and Practice of Moving into Stillness. New York: Pocket Books.

[38] Schön, D. A. (1983) The Reflective Practitioner: How Professionals Think in Action.

[39] Aldershot, UK: Ashgate Publishing Ltd.

[40] Schön, D. A. (1987). Educating the Reflective Practitioner. San Francisco, USA: Jossey-Bass. 
[41] Stanley, J. \& Goddard, C. (2002). In the Firing Line: Violence and Power in Child Protection Work. Chichester, UK: Wiley.

[42] Whitehead, J. (2000). How do I improve My Practice? Creating and legitimating an epistemology of practice. Reflective Practice, 1 (1), 91-104. 